UvA-DARE (Digital Academic Repository)

\title{
The rise of philology: the comparative method, the historicist turn and the surreptitious influence of Giambattista Vico
}

Leerssen, J.T.

Published in:

The making of the humanities. - Vol. 2: From early modern to modern disciplines

Link to publication

Citation for published version (APA):

Leerssen, J. (2012). The rise of philology: the comparative method, the historicist turn and the surreptitious

influence of Giambattista Vico. In R. Bod, J. Maat, \& T. Weststeijn (Eds.), The making of the humanities. - Vol. 2:

From early modern to modern disciplines (pp. 23-35). Amsterdam: Amsterdam University Press.

\section{General rights}

It is not permitted to download or to forward/distribute the text or part of it without the consent of the author(s) and/or copyright holder(s), other than for strictly personal, individual use, unless the work is under an open content license (like Creative Commons).

Disclaimer/Complaints regulations

If you believe that digital publication of certain material infringes any of your rights or (privacy) interests, please let the Library know, stating your reasons. In case of a legitimate complaint, the Library will make the material inaccessible and/or remove it from the website. Please Ask the Library: http://uba.uva.nl/en/contact, or a letter to: Library of the University of Amsterdam, Secretariat, Singel 425, 1012 WP Amsterdam, The Netherlands. You will be contacted as soon as possible. 


\title{
The Making of the Humanities
}

\author{
Volume II: \\ From Early Modern \\ to Modern Disciplines
}

Edited by

Rens Bod,

Jaap Maat and

Thijs Weststeijn 
This book was made possible by the generous support of the

J.E. Jurriaanse Foundation, the Dr. C. Louise Thijssen-Schoute Foundation, and the Netherlands Organization for Scientific Research (NWO).

This book is published in print and online through the online OAPEN library (www.oapen.org)

Front cover:

Hendrik Goltzius, Hermes, I6II, oil on canvas, 214 x $120 \mathrm{~cm}$, Frans Hals

Museum, Haarlem, long-term loan of the Royal Gallery of Paintings

Mauritshuis, The Hague.

Back cover:

Hendrik Goltzius, Minerva, I6II, oil on canvas, 214 X $120 \mathrm{~cm}$, Frans Hals

Museum, Haarlem, long-term loan of the Royal Gallery of Paintings

Mauritshuis, The Hague.

Cover design: Studio Jan de Boer, Amsterdam, the Netherlands

Lay-out: $\mathrm{V}_{3}$-Services, Baarn, the Netherlands
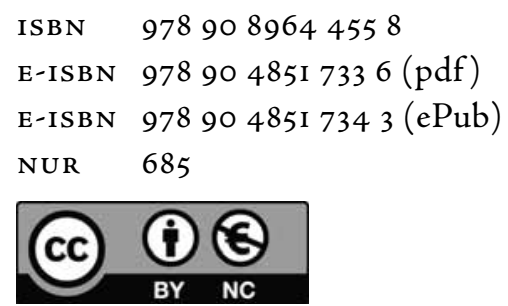

Creative Commons License CC BY NC

(http://creativecommons.org/licenses/by-nc/3.0)

CC) Rens Bod, Jaap Maat, Thijs Weststeijn/ Amsterdam University Press, Amsterdam, 2012

Some rights reserved. Without limiting the rights under copyright reserved above, any part of this book may be reproduced, stored in or introduced into a retrieval system, or transmitted, in any form or by any means (electronic, mechanical, photocopying, recording or otherwise).

Every effort has been made to obtain permission to use all copyrighted illustrations reproduced in this book. Nonetheless, whosoever believes to have rights to this material is advised to contact the publisher. 


\title{
The Rise of Philology
}

\section{The Comparative Method, the Historicist Turn and the Surreptitious Influence of Giambattista Vico}

\author{
Joep LeERsSen
}

\section{Introduction}

A true 'scientific revolution', in the root sense as employed by Thomas Kuhn, took place around 1800 when the study of linguistic relations was placed on a new footing. ${ }^{2}$ Sir William Jones's description of Sanskrit led to a tendency to compare European languages, not with the religious Ursprache Hebrew (as had been the tendency before) but with Sanskrit, and paved the way for a phylogeneticcomparative method full of new insights. It made possible, indirectly, the reclassicifation of linguistic variations as resulting from historically specific vowel or consonant shifts, and a systematic and even nomothetic description of such shifts - for instance, Grimm's famous 'laws' of Lautverschiebung.

This paradigm shift implied a sudden and complete change in the scholarly status of philology and etymology. Philology had been, until the eighteenth century, an obsolete byword for well-read but useless erudition, while etymology was notorious for giving free reign to speculative analogy-hunting between unrelated but superficially similar words from different languages. The paradigm shift is illustrated tellingly by the vehemence with which Friedrich Schlegel, in his Von der Sprache und Weisheit der Inder (1806), in order to vindicate the new Sanskrit-informed and systematic comparatism, denounces happy-go-lucky old-school etymologists. Schlegel sets out, as he states at the conclusion of Book I, to show

nach welchen Grundsätzen etwa eine vergleichende Grammatik und ein durchaus historischer Stammbaum, eine wahre Entstehungsgeschichte der Sprachen, statt der ehemaligen erdichteten Theorien von Ursprungen derselben, zu entwürfen wäre. 
The same Schlegel, in his diaries and around the same time, begins to describe his own work as 'philology', the first sign that that term was being retrieved from near-oblivion.

By 1820 , the notion of philology was being enshrined as the very core of what the humanities were all about. Institutionalized in Humboldt's new university model (implemented for the first time in the University of Berlin), the study of language (until then a mere adjunct for classicists and biblical scholars) was yoked to the study of literature (until then an adjunct for rhetorical studies), and the new twin science of 'Lang. \& Lit.', under the new label of 'Philology' became the very backbone of the new humanities faculties.

Both in its linguistic and in its literary orientation, philology worked, centrally, with a phylogenetic-comparative method. Variants of language or of texts were compared and ordered into a 'family tree'. In language and largely through the work of Franz Bopp, the 'trees' of the Germanic, Romance and Slavic languages were collated with Sanskrit into the master 'tree' of the Indo-European languages, as were, in the course of these decades, languages like Armenian, Albanian, Lithuanian and the Celtic complex. In literary studies, the editorial method pioneered by the towering figure of Karl Lachmann proceeded in a similar fashion: textual variants in various manuscripts were compared and grouped until a 'tree' or stemma of codical relationships could be established springing from a common root or 'Urtext'. Just as linguists could extrapolate vanished words from dead languages by comparing their various descendants, so too editors could extrapolate what must have been in the Urtext by systematizing the various derivative manuscripts. The method was so all-pervasive that it would also be applied to the realm of living organisms (by Ernst Haeckel), influencing the thought of Darwin later that century. ${ }^{3}$

Men like Jacob Grimm applied their new philological method to a variety of fields which are now considered to be widely separate: not only linguistics, textual scholarship and literary history, but also legal studies (especially jurisprudential history) and history-writing, as well as the investigation of folktales and folk beliefs, often with a view towards establishing their roots in ancient mythological belief-systems. ${ }^{4}$ In short, philology in these decades had the ambition to be an all-embracing cultural anthropology of the various nations of Europe in their primordial origins, establishing a nation's cultural profile and outlook by the investigation of its language, poetry, myths and sagas, historiography and legal system.

In what follows, I want to give a slightly more substantial outline of how this programme emerged in the decades after 1800 . In particular, I want to highlight one extremely puzzling and suggestive factor: in developing this programme, the scholars concerned worked very closely along the lines that had been suggested by Giambattista Vico for such a scienza nuova in 1725 ; they even used the name of philology, which Vico had employed as an unfamiliar quasi-neologism in order 
to refer to such a scienza nuova. Yet most of them did so in almost total ignorance of Vico's work, life or even name. So how did Vico's agenda and nomenclature manage to survive their author's obscurity, and influence the philological renewal of the humanities three generations after the appearance of the Scienza nuova?5

\section{The break-up of Enlightenment universalism: Montesquieu to Humboldt by way of Ossian}

Matters of culture, language and literature were, in the Enlightenment, usually discussed in the abstract. The proper study of Mankind is Man, as Alexander Pope put it, and in the philosophical anthropology which we see practised up to and including Kant, words like civility, culture, language, literature and 'man' are used as non-countable abstractions, and usually as singulare tantum - words denoting an undifferentiated whole that cannot be easily put in the plural, much like 'milk,' 'knowledge,' guilt' or 'innocence'. To be sure, comparative contrasts were made in order to better understand the working of a given principle: philosophical historians would treat the succeeding stages and experience of history as so many tests and samples from which to infer moral generalizations, ${ }^{6}$ and moral philosophers might compare national characters, or the various temperaments, or the two sexes, in order to understand human affects such as the susceptibility to beauty or terror. ${ }^{7}$ But these were incidental rather than categorical distinctions.

Language and literature, too, were seen as a varied, yet on the whole undifferentiated whole. Literature was habitually divided into that of 'The Ancients' and 'The Moderns', with the balladry of the Middle Ages intervening, but no categorical divisions were made between Cicero and Shakespeare, Homer and Dante. As Jorge Luis Borges memorably phrased it,

Para el concepto clásico, la pluralidad de los hombres y de los tiempos es accesoria, la literatura es siempre una sola. ${ }^{8}$

Universalism was never universal, of course; there were always counter-positions. The most important in the first half of the eighteenth century was doubtless Montesquieu, who argued that law itself was anything but absolute or universal, and must be germane to the society of its currency: hot climates, for instance, necessitating different constitutions from cold climates. (There is, by the way, some indication that Montesquieu had come across Vico's Scienza nuova, but no direct influence can be inferred from his writings.)

In the second half of the century, the most important counter-position was certainly that of Johann Gottfried Herder. Many Enlightenment philosophers 
had been deeply preoccupied with the origin of language, that premier distinguishing criterion between Man and Beast. Herder turned the question as to the origin of language inside out. If mankind had only one undifferentiated language, he argued, that would amount to no more than a refined instinct, comparable to the bees building honeycombs or birds building nests. What made the human command of language special was its variability, adaptability and diversity. Unlike the one-trick-always-repeated of animal instincts, humankind had spawned a proliferation of different languages adapted to the communication needs of different nations, epochs and climates.

Thus Montesquieu and Herder redefined central human capabilities (lawmaking and language) in terms of their diversity. What made human culture special was its capacity to be plural; what defined it was the way it showed specific differences between nations rather than a generic one-size-fits-all typology.

Finally, after law and language: literature. Into a growing sensitivity to national specificity and diversity and mounting reservations concerning generic-abstract universalism intervened the notorious literary episode of Macpherson's Ossian. The general facts are well known: ${ }^{9}$ how James Macpherson astounded the literary world in 1760 by retrieving fragments of ancient balladry orally handed down in the Scottish Highlands. These fragments caught the literary imagination both because of their lofty, sublime melancholy and their patina of ancient, but forgotten heroes and civilizations. The purported author of these fragments, the bard Ossian, was deemed to have flourished in the Scottish Highlands in the fourth century AD, equal in epic stature to Homer and like him the author of two great epic poems. These were likewise retrieved and reconstituted by Macpherson in the next years, published as Fingal and Temora and they took European literature by storm - helped along to no small extent by Goethe, who interpolated long passages in his success novel The Sorrows of Young Werther (1774). Here was, so Europe realized, another Homer, a Northern one. That in itself was sufficient to drive home the realization that literary civilization, rather than being a monogenist, classically-derived single whole, might in fact be a polygenist force, emerging independently in different parts of the world in analogous form.

The Ossianic vogue lasted for a few decades - longer in some parts of Europe than in others. Ossian's prestige crumbled between 1775 and 1800 under critical scepticism as to the authenticity of Macpherson's translations. By I80o Macpherson was widely discredited as a forger.

Ossian left lasting traces, however ${ }^{10}$ Most importantly, it alerted critics to the possible interchangeability between oral fragment and epic whole; and it gave fresh weight to certain speculations that possibly the Homeric epics themselves, with their formulaic repetitions and their episodic structure, might be the result of a compilation rather than the premeditated and original creation of a single 
inspired individual. The chain of reasoning ran more or less as follows: 'If Ossian is no Northern Homer, maybe Homer was a Southern Macpherson'. The case was made to devastating effect in F.A. Wolf's famous Prolegomena ad Homerum of ${ }^{1795 .}{ }^{\mathrm{II}}$ In this view, Homer was only the compiler of pre-existing rhapsodic fragments that circulated in oral performance. This view tied in with a preference among philologists for 'national epics' that were anonymous, and collective (almost like folktales and folksong). While it took away from the stature of Homer as the genius and origin-point of all literature, it boosted the prestige of what now became known as 'oral epic': orally performed material that was heroic and sublime in tone, and which came to be seen as the type of material which could constitute the elements later to coalesce into a full-length epic.

All this led to a relativism, where each human culture was now seen as an independent entity in its own right, with its own beginnings, language and worldview, separate and non-interchangeable. It was a more 'ecological' view of human culture, and as such an advance beyond the monolithic, and implicitly eurocentric, stance of Enlightenment universalism; but it also opened the door for increasing ethnic essentialism. The processes sketched here also belong to the pre-history of European nationalism. But what separated the late-Enlightenment relativists, like Herder, from the Romantic proto-nationalists was another paradigm shift, as incisive as the discovery of Sanskrit: the historicist turn.

\section{The historicist turn: Savigny to Grimm by way of the 'Wunderhorn' ${ }^{\text {I2 }}$}

In the Napoleon-dominated decade between the abolition of the Holy Roman Empire (I806) and the Battle of Waterloo, the legal scholar Friedrich Carl von Savigny, ${ }^{13}$ Professor of Law at Marburg, was among the most stalwart anti-Napoleonic intellects of his day. He had been trained in the jurisprudential discipline of old-style legal scholarship, where, in order to understand a law system, one had to study its entire historical development - ancien régime jurisprudence being a slow accumulation of successive rulings and regulations based on earlier rulings and customs. The study of law thus became the study of (the word is indeed pregnant) legal custom. A law system was, in this view, the moral and regulative accompaniment of a nation's historical development, organically part of the nation's historical track record. The imposition of a new, French legal system, the Code napoléon, irked legal scholars like Savigny. To have a millennial heritage replaced by a merely instrumental set of regulations devised by an ad-hoc assembly of bickering politicians was, in Savigny's view, a travesty. Savigny became the foremost proponent of an organicist notion of law, which also took in the older views 
as put forward by Montesquieu, that each nation had its own proper legal system much as it had its own language.

In due course, Savigny was to become one of the great legal statesmen of postNapoleonic Prussia. But in pre-1815 Marburg, part of the new-fangled Kingdom of Westphalia ruled by a minor Bonaparte, he was as yet a reserved academic, muttering through clenched teeth in the privacy of his study. In claiming that a law system was the direct expression of nation's specific mentality, Savigny was the first in the German language to give currency to the notion of Volksgeist. ${ }^{14}$

His importance for the argument I am unfolding here lies also in the fact that he served, for a while, as mentor to a bright young law student, whom he trained in the jurisprudential craft of paleography - the study of ancient documents and their provenance, of old types of handwriting and of obsolete forms of the language. At this time, the study and source-criticism of medieval documents was almost the exclusive preserve of legal historians such as Savigny; medieval literature was as yet merely an entertaining fancy for antiquaries and amateurs.

This young scholar thus trained by Savigny was bookishly inclined and even followed his master as an assistant when Savigny went to Paris to consult sources in the Parisian libraries and archives. The young man was none other than Jacob Grimm. ${ }^{15}$ Himself the son of a lawyer (who had died early, leaving him an impoverished half-orphan), Grimm had enrolled at Marburg in order to prepare for a career as a public official through the traditional means of a law degree. Later on he was to choose differently, having meanwhile discovered, among the old documents Savigny introduced him to, the literary riches of the Minnesänger and Reinhart Fuchs. ${ }^{16}$ Even so, he was to remain close to Savigny for the rest of his life and applied to his study of cultural material precisely that historicist organicism that he had learned from his legal mentor and from the craft of jurisprudential source criticism. ${ }^{17}$

Savigny introduced Jacob Grimm, and also Jacob's shy brother Wilhelm, to a set of literary amateurs whose social gatherings he frequented. This was the socalled 'Bökendorf Circle', so named after the country seat of the baronial family Von Haxthausen. The young Haxthausens, August and Werner, had cultural, literary and national interests and received like-minded people (such as their cousin Annette von Droste-Hülshoff, later a renowned author) in what became a regular network. The central node in this network was occupied by Clemens Brentano, who since the beginnings of his Göttingen student days had struck up a close friendship with Achim von Arnim, who married Brentano's sister Bettina in I8II. Brentano's other sister Kunigunde became the wife of, precisely, Savigny.

It was through these associations that the Grimm brothers, as Savigny's protégés, came to attend gatherings at Bökendorf. They were also involved in the collection of folksongs that formed the Bökendorf Circle's chief literary pleasure 


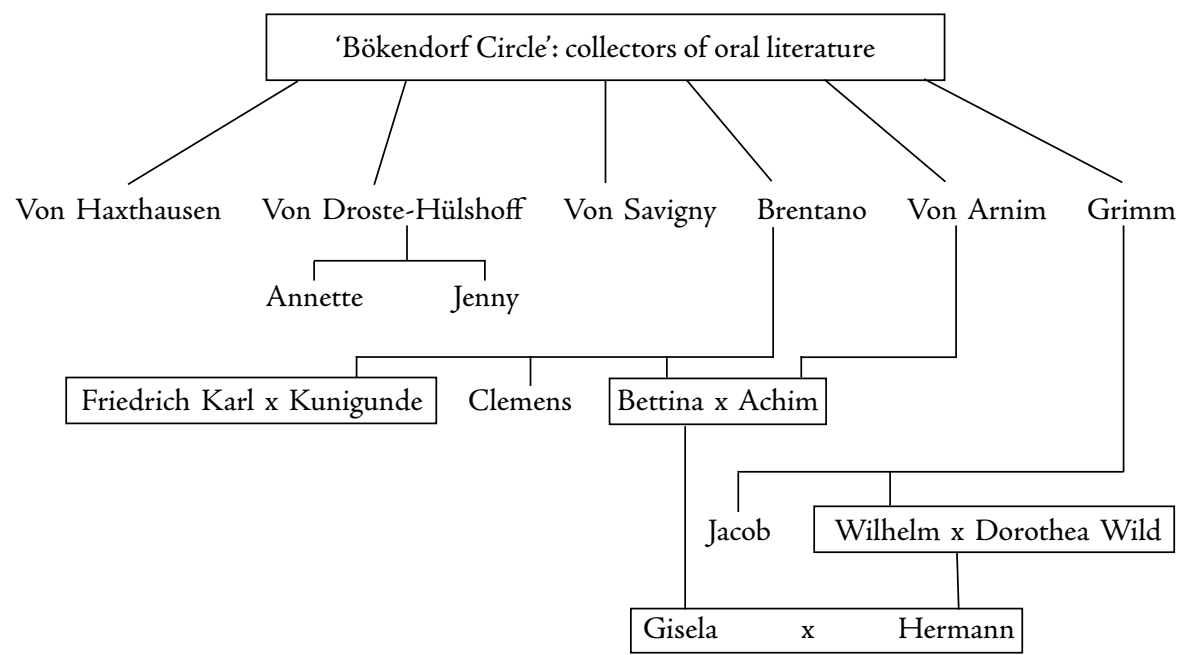

Fig. I: The 'Bökendorf Circle', collectors of oral literature

and that were to culminate in the collection Des Knaben Wunderhorn in 18061807. Edited by Arnim and Brentano, this prototype of all Romantic folksong collections was really the collective effort of the entire Bökendorf Circle. Indeed the Grimms' own collection of fairy tales (the epoch-making Kinder- und Hausmärchen, which appeared in I8I2 and which included material contributed by the Arnims, Brentanos, Haxthausens and Droste-Hülshoffs) may be seen as a prose spin-off of the Wunderhorn. ${ }^{18}$

But there was a difference. Whereas the folk material collected in the Wunderhorn was meant to appeal to sentimentally-inclined readers, who wanted to dip into the naive but charming verses of simple country folk, the interest of Grimm's folk- and fairy tales was different. The Grimms sensed that such tales constituted the oral remains of an older, now-vanished system of supernatural beliefs and sagas of the German nation, the sort of thing that Macpherson had gathered to concoct his Ossian. For the Grimms, pupils of Savigny that they were, the interest of these tales was historicist and anthropological, a window on the primitive mentality of the German nation in its infancy. And so we can trace, from the Wunderhorn (1806) to the Märchen (1812), and thence to the Grimms' Deutsche Sagen (1816) and Jacob Grimm's Deutsche Mythologie (1835) a progress from sentimentalism to philological historicism, and from a dillettante literary interest to hard-nosed academic scholarship.

At the same time, Grimm developed his linguistic skills, coming to the formulation of 'Grimm's Laws' in his Deutsche Grammatik around I820. Again, we can 
see this as the application of Savigny's legal historicism to cultural topics: Grimm looked at language, not as a fixed, closed system, but as a process in a continual state of development, where each phenomenon was to be understood as the product of an evolutionary dynamics. Grimm called it 'das Sein aus dem Werden begreifen' - to understand what is in terms of how it came to be - and always credited his mentor Savigny with inculcating him with this method. ${ }^{19}$

For Grimm and the generations of Germanisten whom he inspired, all the various specialisms they deployed (folklore studies, linguistics, history, literature and jurisprudence) came together in the overriding agenda to understand the nature of the German nation, its origins and national character (witness the insistent use of the word Deutsch in all of Grimm's book titles). Much as astrophysicists nowadays seek to understand the universe by taking their observations back to conditions as close as possible to the Big Bang, so too the historicism of the Grimms led them back towards the most ancient, heroic, epic-collective moments in the nation's history. There, in the tribal beliefs, cults, dialects and lays, before native authenticity was addled by Roman, Christian and foreign influences, lay the moment when the German nation enjoyed a Unity of Culture, when priests, bards and judges were essentially serving one and the same purpose: to articulate what it meant to be properly German. That is what the logos in philology stands for: culture, in the philological view, was an act of national self-creation by self-articulation. Not for nothing does the Grimms' massive Deutsches Wörterbuch carry, for its logo, the opening line of the Gospel according to John: Im Anfang war das Wort - in the beginning was the Word [Fig. 2].

\section{The long shadow of a forgotten godfather: Giambattista Vico}

The notion that each civilization bursts upon the scene of world history in an epic-heroic moment of collective self-articulation, a Big Bang when poetry, mythology/religion and law-making are an undifferentiated whole, when poets are priest and prophets and (as Shelley called it) the unacknowledged legislators of Mankind': that view had been voiced a century before Grimm by the Naples savant Giambattista Vico, in his Scienza Nuova. ${ }^{20}$ The Scienza Nuova, which, as the subtitle phrases it, deals with 'la commune natura delle nazioni', is a gnomic and difficult book, and its full originality only came to be appreciated gradually, in the century after his rediscovery in the I820s-1830s by Edgar Quinet and Jules Michelet. They (like Marx after them) saw Vico essentially as a philosopher of history (more particularly, that peristaltic world history in which civilization goes through successive cycles of youthful vigour, maturity, decrepitude and a fresh beginning). What people took longer to recognize was Vico's anti-Cartesianism, 


\section{JACOB GRIMM UND WILHELM GRIMI.}

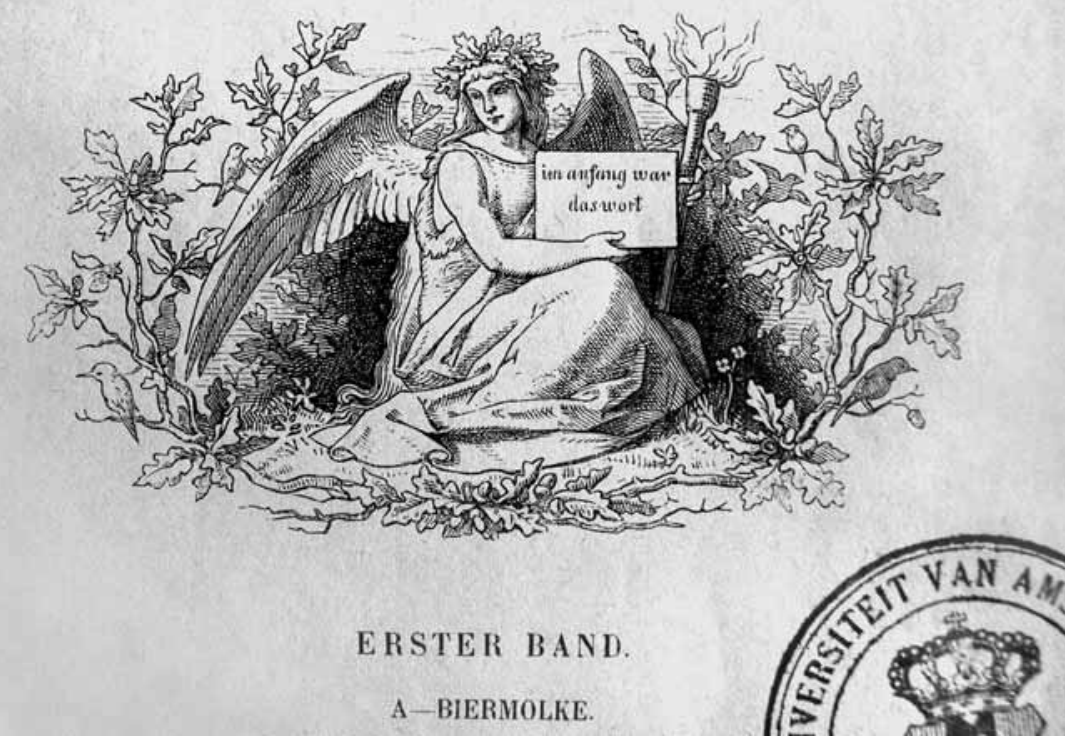

Fig. 2: Im Anfang war das Wort. Vignet on title page of Jacob and Wilhelm Grimm, Deutsches Wörterbuch (Leipzig: Hirzel, I854-1971), 16 vols.

and his view that the mind must use different modes of comprehension for the world around it and for its own mental constructs. The attempts to understand the objective world, Vico calls 'philosophy'; which aims to establish the truth about things. But besides the agenda of philosophy, and given human limitations to understand the world properly, there are those things which emanate from the mind itself: mathematics, mental constructs, epistemic frameworks, in short: culture. This (the verum factum) can be understood with certainty by the mind, because the mind is their author. Thus Vico opposes to the quest for truth the investigation of certainties. The former endeavour he calls 'philosophy', the latter (his 'new science') philology. It is apt to address all those areas in which humans make their own world and mental ambience, through language, law, mythology, poetry and other cultural acts of creation. And it is these which, in a compact Big Bang moment, he sees as the originary moment of each historical civilization.

It will be obvious that both in its coinage of the idea of philology and in its agenda, Vico uncannily foreshadows the endeavours of someone like Grimm, who meant to understand the German mentality and world-view by investigating 
that nation's language, law, mythology and poetry. But was Grimm aware of Vico? Probably not, and in any case not enough to realize how great and substantial the indebtedness was.

This raises the intriguing question how Vicoesque thought and the notion of philology as a cultural anthopology of the nation's antiquity' reached Grimm's generation. Isaiah Berlin has pointed out, in his essays on Counter-Enlightenment intellectuals, that there were remarkable parallels between Vico and Herder, but he failed to substantiate the link or fill in the paper trail leading from one to the other. Names like those of Montesquieu and (especially) Hamann were mentioned, but we may need to look elsewhere for the most promising conduit. Which brings us back to James Macpherson's Ossian.

Ossian had, as I pointed out, a Europe-wide vogue. This was carried by varying translations - an ironic thing for a text which in itself purported to be an English translation from Scottish Gaelic. Besides the passages that Goethe inserted into The Sorrows of Young Werther, one of the more influential translations was an Italian one, by the Paduan antiquary Melchiore Cesarotti, a highly respected name in the history of Italian Enlightenment. ${ }^{21}$ In Venice he published his literary-critical dissertations Sopra l'origine ed i progressi dell' arte poetica and Sopra il diletto della tragedia in 1762 , and shortly after became acquainted with the recently-published Ossianic texts, which he immediately translated into Italian (1763). It earned him great fame and a professorial appointment in his native Padua, where he produced a matching, but less accomplished translation of the Iliad (1786). In his essays and in his annotations to these translations of Homer and Ossian, Cesarotti instills many of his views on the origin and progress of epic poetry, and these, it can be easily seen, are substantially familiar with Vico's Scienza Nuova. ${ }^{22}$ In turn, Cesarotti was known to Herder as a prominent European expert on the Ossianic poems. Cesarotti also obtained the patronage and support of Lord Bute, the Scottish statesman who had funded both some of Macpherson's editions and Cesarotti's translation.

This suggestive line that leads from Vico to Herder by way of Macpherson and Cesarotti may in itself be somewhat tenuous; but it is more suggestive than anything which Isaiah Berlin was able to offer on the topic. ${ }^{23}$ And it is strengthened by the fact that only a few years later, another 'primitive epic' was discovered, again in this intellectual Scottish-Venetian coterie. The Venetian priest Alberto Fortis, a friend of Cesarotti's, undertook a Voyage to Dalmatia, and on that Venetian-controlled but little-known region he published a book in 1774. Part of that book was the presentation of an oral epic noted down in the Dalmatian hinterland from oral recitation, the doleful song of the wife of Hasan-Aga' or Hasanaginica. ${ }^{24}$ Now an uncontested classic of Croatian literature, this freshly discovered tragic-epic poem knew an immediate and enormous éclat in post-Ossianic, pre- 
Romantic Europe. ${ }^{25}$ Once again, Goethe was instrumental (as he had been when he had interpolated Ossian into his Werther, in that selfsame year 1774). His poetic rendition of the Klaggesang der edlen Frau der Hasan-Aga as published in I778 in Herder's epochal anthology of oral literature, the Stimmen der Völker in Liedern, and later again in Goethe's own lyrical collections. The vogue continued for decades. And Alberto Fortis's book was published in an English translation as early as $\mathbf{1 7 7 5}$, with a dedication to its financial sponsor - Lord Bute...

The interest in, and circulation of, a type of heroic poetry taken down as oral fragment and considered to be the folk-collective emanation of a heroic primitivism was in the air and affected a very specific set of Ossian-inspired intellectuals, a network involving Cesarotti and Fortis, Goethe and Herder. ${ }^{26}$ It was through networks like these that Vicoesque notions of primitive folk-collective epic could be carried to affect the young student brought in by Savigny to aid in the preparation of Des Knaben Wunderhorn.

\section{Notes}

I This paper was finished during my fellowship at the Lichtenberg-Kolleg, Göttingen.

2 Hans Aarsleff, The Study of Language in England, 1780-1860 (Princeton, NJ: Princeton University Press, 1967). Anna Morpurgo Davies, Nineteenth-Century Linguistics (London: Longman, I998).

3 Benoît Dayrat, 'The Roots of Phylogeny: How did Haeckel Build his Tree?', Systematic Biology 52.4 (2003), 515-527. Sebastiano Timpanaro, La genesi del metodo del Lachmann (Firenze: Le Monnier, I963).

4 Grimm vindicated the unity of jurisprudence, history and philology proper, under the common name of Germanistik, in his statements as chairman of the first Congress of Germanisten in Frankfurt (I 846), cf. Verbandlungen der Germanisten in Frankfurt am Main am 24., 25. und 26. September 1846 (Frankfurt: Sauerländer, I 836), I4-I 7 and Grimm, Kleinere Schriften (8 vols.; Berlin: Dümmler, I 865-90), 7: 556-63 ('Über die Wechselseitigkeit der drei vertretenen Wissenschaften'). On that occasion and its importance, see Frank Fürbeth et al. (eds.), Zur Geschichte und Problematik der Nationalphilologien in Europa. 150 Jahre Erste Germanistenversammlung in Frankfurt am Main (1846-1996) (Tübingen: Niemeyer, 1999), and Katinka Netzer, Wissenschaft aus nationaler Sebnsucht: Verhandlungen der Germanisten 1846 und 1847 (Heidelberg: Winter, 2006).

5 Generally on the conceptual history of philology, including the role of Vico: Pascale Hummel, Philologus auctor; le philologue et son oeuvre (Bern, Lang: 2003).

6 Thus Voltaire's Essai sur les moeurs, Hume's History of England, Robinson's History of Scotland and Gibbon's Decline and Fall of the Roman Empire.

7 Thus in various climatological sections of Montesquieu's l'Esprit des lois, rebutted in Hume's essay 'Of National Characters', or in Kant's Betrachtungen über das Gefübl des Schönen und Erhabenen.

8 Jorge Luis Borges, 'La postulación de la realidad' (I930), in: Prosa Completa (5 vols., Barcelona: Bruguera), I: $155-60$, esp. I 57 . 
9 The primary corpus has been edited by Howard Gaskill as James Macpherson, The Poems of Ossian and Related Works (Edinburgh University Press, 1996). Two 'classics': Paul Van Tieghem, Ossian et l'Ossianisme dans la littérature européenne au XVIIIe siècle (Groningen: Wolters, I920); Alexander Gillies, Herder und Ossian (Berlin: Junker \& Dünnhaupt, I933). Other fundamental sources: Fiona Stafford, The Sublime Savage: James Macpherson and the Poems of Ossian (Edinburgh University Press, 1988); Fiona Stafford \& Howard Gaskill (eds.), From Gaelic to Romantic: Ossianic Translations (Amsterdam: Rodopi, I998); Howard Gaskill (ed.), The Reception of Ossian in Europe (London: Continuum, 2004).

Io Some of these I have traced elsewhere: 'Ossianic Liminality: Between Native Tradition and Preromantic Taste,' in From Gaelic to Romantic, eds. Stafford and Gaskill, I-I6, and 'Ossian and the Rise of Literary Historicism', in: Gaskill (ed.), The Reception of Ossian in Europe, 109-25. Also: Kristine Louise Haugen, 'Ossian and the Invention of Textual History', Journal of the History of Ideas 59 (1998), 309-327.

I I Reinhart Markner \& Giuseppe Veltri (eds.), Friedrich August Wolf: Studien, Dokumente, Bibliographie (Stuttgart: Steiner, I999). Cf also Wolf's Briefe an Heyne: Eine Beilage zu den neuesten Untersuchungen über Homer (I797).

It should be understood that I deal here with the rise of historicism from another perspective than the usual historiographical, Ranke- and Niebuhr-oriented one, as exemplified in, for example, Stephan Jordan's Geschichtstheorie in der ersten Hälfte des 19. Jahrbunderts. Die Schwellenzeit zwischen Pragmatismus und Klassischem Historismus (Frankfurt: Campus, I999); cf., rather, N.E. Collinge, 'The Introduction of the Historical Principle into the Study of Languages: Grimm, in: Sylvain Auroux et al. (eds.), History of the Language Sciences. An International Handbook on the Evolution of the Study of Language from the Beginnings to the Present (Berlin: De Gruyter, 200I), I 2 10-I223; and Ulrich Wyss, Die wilde Philologie: Jacob Grimm und der Historismus (Munich: Beck, 1979).

I3 Iris Denneler, Friedrich Karl von Savigny (Berlin: Stapp, I985)

I4 Cf. generally Christoph Mährlein, Volksgeist und Recht: Hegels Philosophie der Einheit und ibre Bedeutung in der Rechtswissenschaft (Würzburg: Königshausen \& Neumann, 2000).

I5 The best recent introduction is the biography by Steffen Martus, Die Brüder Grimm: eine Biographie (Berlin: Rowohlt, 20Io).

I6 Cf. my De bronnen van bet vaderland: taal, literatuur en de afbakening van Nederland, 18061890 (2nd ed. Nijmegen: Vantilt, 20 I I).

I7 Wilhelm Schoof (ed.), Briefe der Brüder Grimm an Savigny (Berlin: Erich Schmidt, I953); for the continuing indebtedness, see Ruth Schmidt-Wiegand, 'Das sinnliche Element des Rechts. Jacob Grimms Sammlung und Beschreibung deutscher Rechtsaltertümer', in: L. Denecke (ed.), Kasseler Vorträge in Erinnerung an den 200. Geburtstag der Brüder Jacob und Wilhelm Grimm (Marburg: Elwert, I987), I-24. Also, my 'From Bökendorf to Berlin: Private Careers, Public Sphere, and How the Past Changed in Jacob Grimm's Lifetime', in: L. Jensen et al. (eds.), Free Access to the Past: Romanticism, Cultural Heritage and the Nation (Leiden: Brill, 2010), 55-70.

I 8 Heinz Rölleke, 'Die Beiträge der Brüder Grimm zu “Des Knaben Wunderhorn”, Brüder Grimm Gedenken 2 (1975), 28-42.

I9 Maria Herrlich, Organismuskonzept und Sprachgeschichtsschreibung. Die 'Geschichte der deutschen Sprache' von Jacob Grimm (Hildesheim: Olms-Weidmann, I998).

From amidst the great deal of secondary literature I select Peter Burke's brief but insightful Vico (Oxford University Press, I984).

2 I Cf. Emilio Bigi, Dal Muratori al Cesarotti 4: critici e storici della poesia e delle arti nel secondo settecento (Milano: Ricciardi, I960). Interesting information is also contained in Lesa 
Ní Mhunghaile, 'Joseph Cooper Walker, James Macpherson agus Melchiorre Cesarotti', Eighteenth-Century Ireland I7 (2002), 79-98 and Gustavo Costa, 'Melchiorre Cesarotti, Vico and the Sublime', Italica 58 (I98I), 3-15.

22 Enrico Mattioda, 'Ossian in Italy: From Cesarotti to the Theatre', in: Gaskill, The Reception of Ossian in Europe, 274-302.

23 The case was first made by Robert T. Clark ('Herder, Cesarotti and Vico', Studies in Pbilology 44.4 (1947), 645-67I). It was reiterated by Arthur H. Scouten in his review of Berlin's Vico and Herder (in Comparative Literature Studies I5.3 (1978), 336-34I. Berlin's reply to Scouten ('Professor Scouten on Herder and Vico', Comparative Literature Studies I6.2 (I979), I4I-I45) showed considerable bluster ('This really will not do') but does little else than admit the case as made by Clark, and claim that he, Berlin, was aware of it despite Scouten's cavils.

24 It has been reprinted as Alberto Fortis, Viaggio in Dalmazia, ed. P. Rehder (Munich: Sagner, 1994). An excellent analysis is given by Larry Wolff, Venice and the Slavs: The Discovery of Dalmatia in the Age of Enlightenment (Stanford, CA: Stanford University Press, 200I).

25 A very extensive documentation of the reception record is given by Alija Isakovic (ed.), Hasanaginica 1774-1974 (Sarajevo: Svjetlost, 1975).

26 Cf. Barbara W. Maggs, 'Three Phases of Primitivism in Portraits of Eighteenth-Century Croatia', Slavonic and East European Review 67.4 (1989), 546-563. 